\title{
GENEZA MAJORATU I STOSUNKI OSADNICZE W DOBRACH RODZINY TOLLÓW POD UNIEJOWEM
}

Zarys treści: Artykuł przedstawia stosunki osadnicze w obrębie dóbr majorackich w rejonie Uniejowa w XIX i początkach XX w. Analizy geohistoryczne objęły zagadnienia genezy oraz przemian osadniczych z uwzględnieniem morfologii wsi. Artykuł jest próbą rekonstrukcji okoliczności powstania donacji na podstawie ukazu z $1836 \mathrm{r}$. oraz rozwoju wybranych aspektów społecznych i gospodarczych funkcjonowania badanego majoratu w ujęciu przestrzennym. Szczególną uwagę zwrócono na kwestię przemian osadnictwa wiejskiego pod wpływem realizacji wielkich reform agrarnych skutkujących transformacją układów ruralistycznych.

Słowa kluczowe: geografia historyczna, osadnictwo, wieś, rodzina Tollów, majorat, XIX wiek, Uniejów

\section{WPROWADZENIE}

Po klęskach powstań listopadowego i styczniowego na terenie całego Królestwa Kongresowego wzmagały się represje i prześladowania. Jedną z form działań odwetowych wobec społeczeństwa polskiego było przekazywanie pokaźnych majątków ziemskich carskim dygnitarzom. Proces rozdawnictwa dóbr ziemskich zapoczątkowano w $1835 \mathrm{r}^{1}{ }^{1}$ Przebiegał on w sposób długotrwały i wieloetapowy w latach 1835-1845 i 1865-1869. Liczba donacji rosyjskich utworzonych w Królestwie Polskim przekraczała ponad 200. Obejmowały one przeszło milion mórg

* Monika Cepil, studentka II roku uzupełniających studiów magisterskich w zakresie geografii, Uniwersytet Łódzki, Wydział Nauk Geograficznych, email: monika_cepil@wp.pl.

** Tomasz Figlus, dr, adiunkt, Uniwersytet Łódzki, Wydział Nauk Geograficznych, Katedra Geografii Politycznej, Historycznej i Studiów Regionalnych, ul. Kopcińskiego 31, 90-142, Łódź, email: tomasz.figlus@gmail.com

1 Dziennik Praw Królestwa Polskiego (dalej: DzPKP) 1836, t. 17, s. 339. 
i istniały formalnie do końca I wojny światowej². Ogółem na donacje przeznaczono 837 wsi, czyli 6,1\% wszystkich osad w Królestwie Polskim ${ }^{3}$.

Proces tworzenia majoratów w historiografii określany jest mianem donacji paskiewiczowskich. Generał Iwan Paskiewicz był głównodowodzącym wojskami rosyjskimi podczas powstania listopadowego, zaś od $1832 \mathrm{r}$. sprawował funkcje namiestnika Królestwa Polskiego ${ }^{4}$. Donacje stanowią interesujące zjawisko polityczne, prawne i ekonomiczne. Rozwijały się one w wyniku polityki rusyfikacyjnej caratu, a ich powstawanie przypadło na okres wielkich reform agrarnych.

W bogatej literaturze poświęconej problematyce osadniczej w XIX w. sprawa majoratów przez długi czas pozostawała na uboczu zainteresowań badaczy. W historiografii polskiej na uwagę zasługuje w szczególności przeglądowa praca J. Kukulskiego ${ }^{5}$, poświęcona w głównej mierze rozważaniom prawno-ustrojowym i politycznym. W geohistoriografii występuje natomiast brak kompleksowych badań, które ukierunkowane byłyby na kwestie odnoszące się do poszczególnych majoratów, jako zwartych struktur przestrzennych. W tej sytuacji uzasadnione było podjęcie przez autorów artykułu pogłębionych studiów obejmujących kwestię donacji w obrębie dawnych dóbr uniejowskich, należących przed sekularyzacją do arcybiskupów gnieźnieńskich ${ }^{6}$. Głównym celem pracy było zbadanie genezy i przebieg rozwoju majoratu rodziny Tollów, przeanalizowanie procesu zmian stosunków osadniczych obejmujących elementy sfery społeczno-gospodarczej w ujęciu przestrzennym. Na potrzeby opracowania podjęto kwerendy w Archiwum Państwowym w Lodzi oraz Archiwum Głównym Akt Dawnych w Warszawie. Przestudiowano akty normatywne dotyczące kwestii majoratów, analizie poddano źródła statystyczno-demograficzne oraz archiwalne materiały na temat gospodarczo-agrarnej sfery funkcjonowania majoratu uniejowskiego. Niezwykle istotne dla poruszanej problematyki okazały się także rękopiśmienne źródła kartograficzne odnoszące się do wsi na badanym obszarze ${ }^{7}$.

\section{GENEZA DONACJI NA RZECZ RODZINY TOLLÓW W REJONIE UNIEJOWA}

W pierwszej połowie XIX w. dobra Ekonomii Rządowej Uniejów zostały podzielone na trzy majoraty: Uniejów-Kościelnica (12088 mórg), Chełmno

2 W. Grabski, Historia wsi w Polsce, Warszawa 2004, s. 27; J. Kukulski, Donacje paskiewiczowskie w okresie reform agrarnych, Kielce 1987, s. 3.

3 J. Kukulski, Państwo - chłopi - kościót w okresie wielkich reform ziemskich Królestwa Polskiego w latach 1768-1890, Piotrków Trybunalski 2007, s. 87.

4 S. Piątkowski, Majorat Iwana Paskiewicza w guberni lubelskiej (1840-1856). Karta z biografii Księcia Namiestnika Królestwa Polskiego, [w:] A. Koprukowniak (red.), Studia $z$ dziejów ziemian 1795-1944, Lublin 2005, s. 179.

5 J. Kukulski, Donacje paskiewiczowskie..., s. 1-14.

6 T. Figlus, Rozwój osadnictwa wiejskiego w kluczu uniejowskim dóbr arcybiskupów gnieźnieńskich, „Biuletyn Uniejowski” 2016, t. 5, s. 5-28.

7 M. Chilczuk, Osadnictwo wiejskie Polski (Formy i uklady przestrzenne), Warszawa 1970, s. 19. 
(2799 mórg) i Niemysłów (4107 mórg) (ryc. 1) ${ }^{8}$. Warto wspomnieć, że majorat Chełmno został nadany gen. K. Bistromowi, a Niemysłów radcy stanu G. Massonowi ${ }^{9}$. Zgodnie z założeniami, niniejszy artykuł odnosi się wyłącznie do kwestii przemian osadnictwa wiejskiego $\mathrm{w}$ dobrach majorackich położonych w bezpośrednim sąsiedztwie Uniejowa.

Zarządzeniem carskim z dnia 14 XII 1836 r. majorat Uniejów-Kościelnica, posiadający powierzchnię 12088 morgów, znalazł się w posiadaniu generała piechoty hrabiego Karla Wilhelma von Tolla ${ }^{10}$. Dobra uniejowskie były benefitem dla rosyjskiego dowódcy za zasługi na rzecz cara w czasie powstania listopadowego ${ }^{11}$.

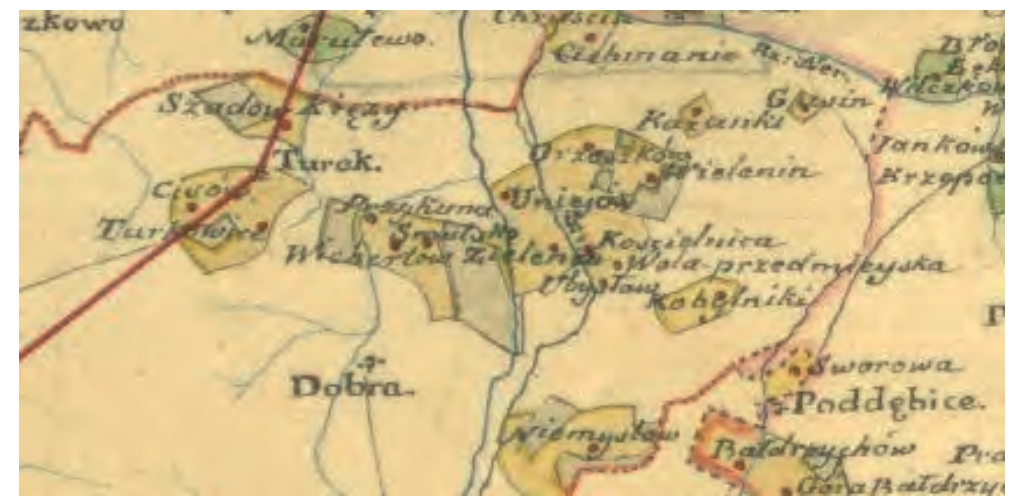

Ryc. 1. Dobra Rządowe Ekonomii Uniejów na Mapie Ogólnej Dóbr i Lasów Rządowych w Królestwie Polskim, ułożonej przez J. Rakowskiego w 1825 r. Źródło: AGAD, Zbiór kartograficzny, sygn. 88-10

Karl Fiodorowicz (Karl Wilhelm) Toll (ros. Карл Вильгельм Фёдорович Толь) urodził się 8 IV 1777 r. w Lääne na terenie dzisiejszej Estonii. Pochodził ze starego niemiecko-bałtyckiego rodu von Toll, posiadał również korzenie holenderskie. Rodzina wywodziła się z okolic Lejdy (Leiden) ${ }^{12}$. Karl Toll wraz z żoną Olgą von Strandman i czterema synami Aleksandrem (ur. 1816 r.), Konstantym (ur. 1817 r.), Mikołajem (ur. 1819 r.) i Karolem Wilhelmem jr (ur. 1834 r.), mieszkali początkowo na terenie Estonii (ryc. 2). W 1796 r. K. W. Toll ukończył Korpus Kadetów. Był zawodowym żołnierzem, brał udział m.in. w kampanii przeciwko Francji w 1805 r. i w wojnie przeciwko Turcji w latach 1806-1809. W trakcie powstania listopadowego gen. Toll był jednym z głównych dowódców w bitwie pod Ostrołęką w 1831 r. oraz szefem sztabu gen. Iwana Dybicza

8 Archiwum Główne Akt Dawnych w Warszawie (dalej: AGAD), Zbiór kartograficzny, sygn. 88-10.

9 Stownik Geograficzny Królestwa Polskiego i innych krajów słowiańskich (dalej: SGKP), red. B. Chlebowski, F. Sulimierski, t. 12, Warszawa 1882, s. 804.

${ }^{10}$ B. Pełka, Lata zaborów, [w:] J. Szymczak (red.), Uniejów. Dzieje miasta, Uniejów-Łódź 1995, s. 181.

${ }^{11}$ L. Krantz, Zamek w Uniejowie, Warszawa-Poznań 1980, s. 55.

${ }_{12}$ Genealogisches Handbuch der baltischen Ritterschaften, Teil 2: Estland, Görlitz 1930, s. 434. 
i Iwana Paskiewicza. Cieszył się opinią człowieka o wielkiej energii i znakomitych zdolnościach dowódczych. Po powstaniu działał jako dygnitarz w sferze administracji publicznej. W latach 1833-1839 zarządzał siecią komunikacyjną i budowlami publicznymi w Królestwie Polskim ${ }^{13}$. W trakcie swojej wieloletniej służby uzyskał wiele nagród i wyróżnień m.in. order św. Jerzego 4-go stopnia (1812), order św. Anny 1-go stopnia i diamentową odznakę (1813), order św. Włodzimierza 2-go stopnia (1813) oraz order św. Jerzego 2-go stopnia (1829) ${ }^{14}$. Warto dodać, że gen. Toll nigdy nie zobaczył otrzymanego majoratu, gdyż stan zdrowia nie pozwalał opuszczać mu Estonii. Zmarł 23 IV 1842 r. w majątku Arroküll na terenie Estonii ${ }^{15}$.

W dniach 4/16 X 1835 r. został wydany ukaz składający się z 27 artykułów, z postanowieniami dotyczącymi donacji. Wedle ukazu wysokość donacji podzielono na 4 klasy: do I klasy zaliczono dobra, które dawały obdarowanemu roczny dochód 30 tys. złp. Donacje te przyznawano generałom broni i urzędnikom stopnia drugiego. Do klasy II zaliczono dobra z dochodem 20 tys. złp. Obdarowano nimi generałów lejtnantów i urzędników stopnia trzeciego. Do klasy III zaliczono donacje, które miały przynosić 10 tys. złp. rocznego dochodu i przeznaczono je dla generałów majorów i urzędników stopnia czwartego. Dochody roczne do 5 tys. złp. występowały w donacji IV klasy. Otrzymali je pułkownicy, podpułkownicy oraz dowódcy niższego stopnia ${ }^{16}$. K. W. Toll został zaliczony do klasy I, jak już wspomniano powyżej z dochodem rocznym 30 tys. złp. ${ }^{17}$ Według wykazu donacji utworzonych w $1836 \mathrm{r}$. oprócz Tolla tak dużym majoratem obdarowano jeszcze tylko gen. lejt. A. Kreytza. Został on właścicielem donacji w Kole ${ }^{18}$.

W skład donacji Uniejów-Kościelnica weszły wsie wraz folwarkami: Kościelnica, Orzeszków, Ubysław, Wielenin i Zielenin ${ }^{19}$ oraz wsie Ostrowsko, Człopy, Spicymierz z osadą leśną Malczewem, Wola Przedmiejska i Brzeziny ${ }^{20}$. Warto dodać, że własnością Tollów były tylko grunty należące do Skarbu Państwa. Natomiast wszystko, co znajdowało się na gruntach włościańskich, magazyny i własności grodzkie pozostało w rękach dotychczasowych właścicieli²1.

${ }_{13}$ J. Kukulski, Generałowie carscy i ich majątki ziemskie w Królestwie Polskim (1835-1920), Warszawa 2007, s. 28 i 348; M. Leszczyński, Ostrotęka 1831, Warszawa 2011, s. 34 i n.; T. Wójcik, Tollowie, „W Uniejowie - Pismo Towarzystwa Przyjaciół Uniejowa” 2016, nr 67, s. 14-16.

${ }^{14}$ T. von Bernhardi, Denkwürdigkeiten aus dem Leben des Grafen von Toll, 2. Auflage, Leipzig 1866

${ }^{15}$ T. Wójcik, Tollowie..., s. 14.

16 J. Kukulski, Donacje paskiewiczowskie..., s. 13; DzPKP 1836, t. 17. s. 323-367.

17 Tenże, Generałowie carscy..., s. 86.

${ }_{18}$ Tenże, Donacje paskiewiczowskie..., s. 162 i n.

${ }_{19}$ DzPKP 1837, t. 20, s. 347 i n.; G. Myszkorowska-Olczak, Zespoły folwarczne na terenie gminy Uniejów, „Biuletyn Uniejowski” 2013, t. 2, s. 99; B. Pełka, Lata zaborów..., s. 181; SGKP, t. 12, Warszawa 1892, s. 804.

${ }^{20}$ Archiwum Państwowe w Łodzi (dalej: APŁ), Urząd Gubernialny Kaliski do Spraw Włościańskich, sygn. 964.

${ }^{21}$ DzPKP 1837, t. 20, s. 358-359. 


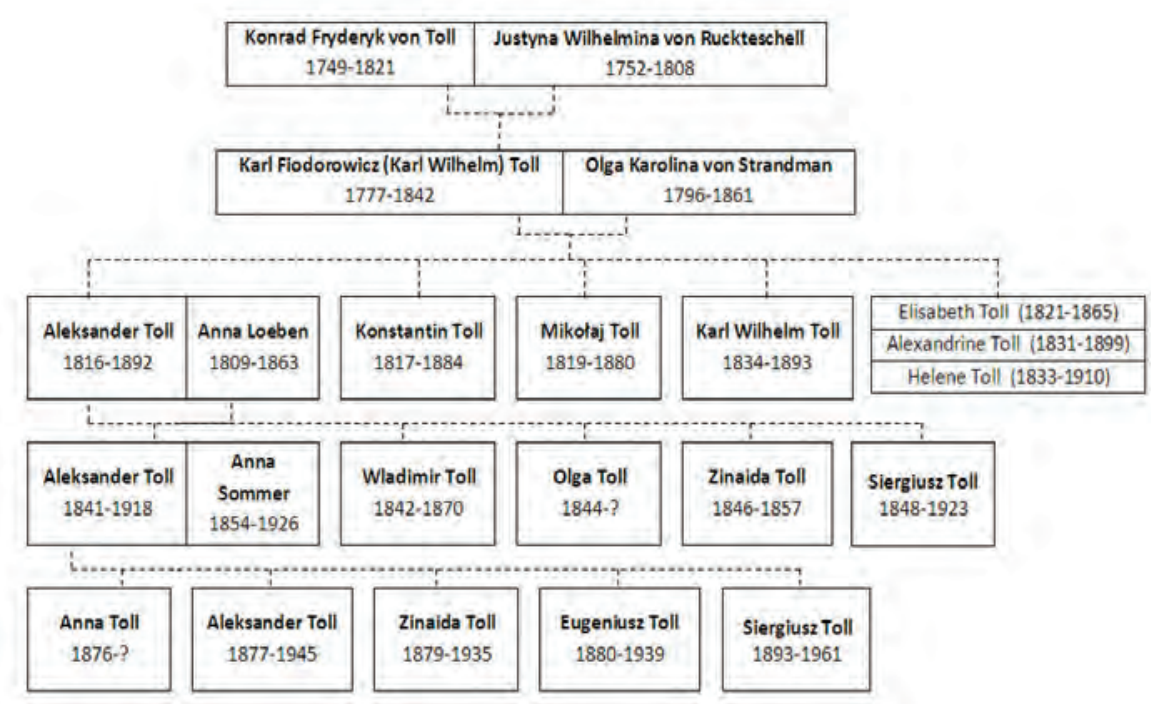

Ryc. 2. Fragment drzewa genealogicznego rodziny Tollów

Źródło: opracowanie na podstawie: Genealogisches Handbuch der baltischen Ritterschaften, Teil

2: Estland, Görlitz 1930, s. 433-435 oraz danych na witrynie genealogicznej: geneall.net/

\section{STOSUNKI OSADNICZE W DOBRACH MAJORACKICH TOLLÓW NA TLE STRUKTUR SPOŁECZNO-GOSPODARCZYCH}

Zgodnie z obowiązującym prawem donacje mogły przechodzić na następców tylko w drodze spadku, zawsze na najstarszego syna, będącego wyznania prawosławnego ${ }^{22}$. Po śmierci gen. W. K. Tolla, właścicielem i faktycznym zarządcą dóbr uniejowskich został jego syn hr. Aleksander Toll23, który wraz z żoną Anną von Loeben posiadał jedynego syna o imieniu Aleksander. Po śmierci ojca stał się on kolejnym i ostatnim sukcesorem dóbr majorackich w rejonie Uniejowa ${ }^{24}$.

Nowy właściciel wszedł w posiadanie majątku w chwili wydania ukazu nadawczego i od tego momentu miał prawo do pobierania dochodów. Donacja użytkowania nastąpiła w dniu 1 I 1837 r. Jednak faktyczne przejęcie dóbr miało miejsce 1 VI 1838 r. Z tytułu uzyskanego majątku gen. Toll otrzymywał od kasy skarbowej należny mu dochód w czteromiesięcznych ratach ${ }^{25}$.

Do nabywcy należały obowiązki płacenia podatków i składek narzuconych przez rząd. Toll przyjmując majorat, był zobowiązany do płacenia wszystkich istniejących zadłużeń ziemskich. W kontrakcie znajdował się również punkt mó-

\footnotetext{
${ }^{22}$ J. Kukulski, Donacje paskiewiczowskie..., s. 25.

${ }^{23}$ B. Pełka, Lata zaborów..., s. 181.

${ }^{24}$ T. Wójcik, Tollowie..., s. 14.

${ }^{25}$ DzPKP 1837, t. 20, s. 365.
} 
wiący o opłatach i należnościach w stosunku do Skarbu Państwa. W przypadku zaległości dobra ziemskie zostałyby zabrane przez administrację rządową na tak długo, aż nie zostanie uiszczona opłata. Dobra donacyjne nie mogły być także sprzedane ani oddane za długi ${ }^{26}$.

Do nie najłatwiejszych zadań należało urządzanie dóbr donacyjnych, zwłaszcza, że przypadło ono na okres zaniku stosunków feudalnych i przemian agrarno-gospodarczych. Została wtedy zapoczątkowana wielka reforma polegająca na przechodzeniu ku kapitalistycznym stosunkom społeczno-produkcyjnym $^{27}$. W kontrakcie donacyjnym zagwarantowano włościanom dotychczasowe ich prawa, a w II połowie XIX w. dokonano likwidacji pańszczyzny.

Ukaz carski zobowiązywał rodzinę Tollów do reorganizacji ziemi włościańskiej w ciągu 6 lat od chwili objęcia majoratu ${ }^{28}$. Urządzenie miało być przeprowadzone na drodze separacji gruntów folwarcznych i włościańskich oraz dokonania kolonijnej przebudowy siedlisk wiejskich ${ }^{29}$. Proces ten, zgodnie z założeniami, powinien zakończyć się w $1843 \mathrm{r}$. W tym okresie mieszkańcy majoratu odrabiali pańszczyznę, a z czasem uiszczali opłatę w pieniądzu. Likwidacja dawnych powinności i ustalenie nowych świadczeń odbywały się pod opieką i nadzorem rządu. Zamiana pańszczyzny na czynsz (tzw. komutacja) nastąpiła dopiero po całkowitym urządzeniu wsi. Do tego czasu chłopi byli zobowiązani do pełnienia posługi na rzecz pana $3 \mathrm{dni}$ w tygodniu ${ }^{30}$. W kontrakcje donacyjnym znalazł się również punkt mówiący o nowo powstałych budowlach w obrębie majoratu Tolla. Wznoszenie zabudowy włościańskiej, gdyby podczas urządzenia powstała taka potrzeba, miały być stawiane kosztem gruntów właściciela, który miał prawo żądać od włościan pomocy w robociźnie ${ }^{31}$.

Pomimo odgórnych nakazów, ludność chłopska buntowała się i występowała przeciwko powinnościom feudalnym. W $1845 \mathrm{r}$. w dobrach należących do Aleksandra Tolla, doszło do buntu 150 chłopów. Doceniając powagę sytuacji, naczelnik powiatu kaliskiego wysłał do majątku 10 kozaków. Ich zadaniem było przywrócenie porządku i zmuszenie włościan do posłuszeństwa ${ }^{32}$. W tym kontekście warto dodać, że Aleksander Toll prowadził długotrwałe zatargi z mieszkańcami wsi Orzeszków ${ }^{33}$.

Jak wcześniej wspomniano kontrakt gwarantował Tollom posiadanie donacji na zasadach własności zupełnej z tym jednak, że obdarowani przyjmowali dobra

${ }^{26}$ Tamże, s. 251, 363, 370.

27 J. Kukulski, Donacje paskiewiczowskie..., s. 40-42

${ }^{28}$ DzPKP 1837, t. 20, s. 351.

${ }^{29}$ A. Tuderek, Wieś Księżomierz - stosunki gospodarczo-społeczne w XIX stuleciu, „Teka Komisji Historycznej OL Lublin" 2009, 6, s. 190.

${ }^{30}$ DzPKP 1837, t. 20, s. 351-355.

${ }^{31}$ Tamże, s. 355.

32 B. Szczepański, Rozwój rolnictwa, [w:] W. Jakóbczyk (red.) Dzieje Wielkopolski, t. 2, Poznań 1973, s. 785.

${ }^{33}$ T. Grabarczyk, A. Kowalska-Pietrzak, J. Szymczak, Uniejowskie strony - karty z przeszłości odległej, nieznanej i bliskiej gminy Uniejów, Łódź-Uniejów 2008, s. 101. 
z różnymi enklawami własności, które wypływały z mocy aktów urzędowych wniesionych wcześniej do hipoteki lub z przywilejów przysługujących chłopom i kolonistom dóbr skarbowych ${ }^{34}$. Według umowy z rządem z 1832 r. w wieczystej dzierżawie Bogumiła Marczewskiego pozostał folusz na rzece Warcie w Kościelnicy wraz z przynależącymi do niego gruntami i placem wojskowym. Również w Kościelnicy ex antiquo zgodnie z przywilejem arcybiskupa gnieźnieńskiego z 1780 r. Paweł Wiktor miał w dzierżawie młyn wodny i grunty do niego należące, za opłatę trzech rubli. Po sąsiedzku wedle postanowienia Kamery Kaliskiej z 1802 r. Beniaminowi Marczewskiemu przysługiwało prawo wieczystej dzierżawy dwóch wiatraków. Lechowi Gancarskiemu z Uniejowa przysługiwało prawo do kopania gliny w obrębie Kościelnicy, za opłatą 72 złp. Prawo to nabyli jego przodkowie w $1645 \mathrm{r}$. od arcybiskupa gnieźnieńskiego. We wsi Ostrowsko prawo wieczystej dzierżawy jednej morgi z postawionym na niej wiatrakiem przysługiwało ponadto Janowi Marzewskiemu. Prawo to nabył w 1829 r. za opłatą czynszu rocznego wysokości 30 złp. W donacji znalazła się także jedna osada leśna Malczew. Prawo do jej wieczystego użytkowania posiadali Bogusław i Karolina Kleine. Czynsz z kolonii o powierzchni 57 mórg i 276 prętów wynosił 116 złp. i gr 9 rocznie $^{35}$.

Kłopotliwe dla właścicieli majoratu okazało się utrzymanie przepraw na rzece Warcie, dlatego usilnie chcieli je przekazać kasie miejskiej w Uniejowie. W obrębie majoratu znajdował się główny most na Warcie łączący osadę z zamkiem oraz traktami do Kalisza i Turku, oraz 6 innych małych mostów na jej dopływach. W $1864 \mathrm{r}$. toczyły się w tej sprawie rozmowy w zamku z udziałem naczelnika powiatu kaliskiego, inżyniera gubernialnego i powiatowego oraz dwóch ławników miejskich. Hr. Toll przekonywał ich, że opłaty taryfowe wpłyną na polepszenie kasy miejskiej. Ci jednak odmówili przejęcia mostu. Tłumaczyli się, że nie mają zgody mieszkańców i nie posiadają drewna na naprawę. W latach 1880-1882 Rząd Gubernialny uwolnił Tolla od utrzymania mostu i pobierania opłat taryfowych, które wpłacał regularnie do Kaliskiej Izby Skarbowej. Zarządzanie mostem w 1883 r. przejął Rząd Gubernialny Kaliski i oddał go w dzierżawę ${ }^{36}$.

Przejmowane folwarki zazwyczaj były w złym stanie i w związku z tym nie przynosiły dużych dochodów ${ }^{37}$. Majoraty bardzo rzadko znajdowały się pod bezpośrednim nadzorem właściciela, w większości przypadków majątkiem zarządzali pełnomocnicy ${ }^{38}$. Omawiany majątek znajdował się pod bezpośrednim zarządem rodziny Hofmajstrów. Prywatnie rodzina była spokrewniona z Tolla-

${ }^{34}$ J. Kukulski, Donacje paskiewiczowskie..., s. 24.

${ }^{35}$ APŁ, Urząd Gubernialny Kaliski do Spraw Włościańskich, sygn. 964.

36 APŁ Rząd Guberni Kaliskiej, sygn. 2334; B. Pełka, Lata zaborów..., s. 209.

${ }^{37}$ G. Myszkorowska-Olczak, Zespoly folwarczne..., s. 100.

${ }^{38}$ R. Chomać, Zmiany własności struktury agrarnej guberni kaliskiej w latach 1864-1914, „Rocznik Kaliski” 1968, 1, s. 173. 
$\mathrm{mi}^{39}$. W ich rękach znajdowały się fundusze na remonty i uposażenia folwarków, lecz często nie wywiązywali się oni z powierzonych im zadańn ${ }^{40}$.

Jedną z najważniejszych reform za życia hr. Aleksandra Tolla w obrębie posiadanego przez niego majoratu było niewątpliwie uwłaszczenie chłopów. Reforma uwłaszczeniowa objęła oprócz majoratów także dobra prywatne, instytutowe i rządowe. 2 marca 1864 r. zgodnie z ukazem carskim wdrożono w życie zapisy zmieniające dotychczasowe stosunki osadnicze ${ }^{41}$. Chłopi mający w posiadaniu ziemie zostali uwłaszczeni ${ }^{42}$. Z nadziałów wyłączono służbę folwarczną i robotników najemnych, którzy mieszkali w bezpośrednim sąsiedztwie zabudowań folwarcznych, co wywołało duże zaniepokojenie ${ }^{43}$. Komitet Urządzający pomimo wielu skarg nie uwzględnił żądań tej grupy społecznej ${ }^{44}$. Na mocy reformy uwłaszczeniowej między włościan rozdzielono: w Brzezinach 445 morgów i 73 pręty, w Człopkach 178 morgów i 89 prętów, w Czopach 747 morgów i 20 prętów, w Kościelnicy 456 morgów i 298 prętów, w Orzeszkowie nadział 516 mórg i 127 prętów, w Ostrowsku 1522 morgów i 24 pręty, w Spicymierzu 1381 mórg i 183 pręty, w Wieleninie 787 mórg i 125 prętów i w Woli Przedmiejskiej 507 mórg i 58 prętów ${ }^{45}$. Ogółem chłopom przyznano 6788 mórg i 136 prętów. W wyniku przeprowadzonej reformy łączna powierzchnia gruntów w folwarkach należących do rodziny Tollów wynosiła 5676 morgów ziemi, w tym ok. 2900 mórg lasu. Dochód z folwarków oszacowano w 1899 r. na 25 tys. rb. ${ }^{46}$

Do końca 1866 r. wydano rozporządzenie, które miało na celu uzupełnić straty spowodowane uwłaszczeniem chłopów. Aleksandrowi Tollowi w ramach zadośćuczynienia przyznano folwark Grzybki w ekonomii Brodnia oraz część lasu z nadleśnictwa Turek, według szacunkowych danych z dochodem rocznym ponad $250 \mathrm{rb}^{47}$. W $1866 \mathrm{r}$. wydano ponadto prawo pozwalające mieszkańcom ze wsi Kościelnica, Ostrowsko i Spicymierz na łowienie ryb w Warcie w miejscach przyległych do gruntów stanowiących własność włościan w tychże wsiach ${ }^{48}$.

Przejdźmy teraz do omówienia kwestii zaludnienia, zabudowy i powierzchni gruntów w osadach wchodzących w skład majoratu należącego do rodziny Tollów. Można dostrzec znaczne dysproporcje wielkości wsi, biorąc pod uwagę przyjęte do analizy kryteria (tab. 1). Największymi wsiami w badanym kluczu

${ }^{39}$ T. Grabarczyk i in., Uniejowskie strony - karty..., s.101.

${ }^{40}$ G. Myszkorowska-Olczak, Zespoty folwarczne..., s. 100.

${ }^{41}$ K. Groniowski, Uwłaszczenie chłopów w Polsce, Warszawa 1976, s. 131 i n; Z. Stankiewicz, Zasady uwłaszczenia chłopów w Królestwie Polskim, [w:] Studia i Materiały do Dziejów Łodzi i okręgu łódzkiego. Uwłaszczenie chłopów i mieszczan rolników, red. H. Brodowska, Łódź 1966, s. $57 \mathrm{i} \mathrm{n.}$

${ }^{42} \mathrm{H}$. Brodowska, Historia społeczno-gospodarcza chłopów w zaborze rosyjskim, [w:] Historia chłopów polskich, t. 2, red. S. Inglot, Wrocław 1972, s. 404.

${ }^{43}$ W. Grabski, Bezrolni i majoraty, „Biblioteka Warszawska” 1910, 70 (829), s. 98.

${ }^{44}$ B. Pełka, Lata zaborów..., s. 198.

45 APŁ, Urząd Gubernialny Kaliski do Spraw Włościańskich, sygn. 964.

${ }^{46}$ B. Pełka, Lata zaborów..., s. 198.

${ }^{47}$ DzPKP 1866, t. 66, s. 79; R. Chomać, Zmiany własności..., s. 176.

${ }^{48}$ APŁ, Urząd Gubernialny Kaliski do Spraw Włościańskich, sygn. 964. 
majątkowym w XIX w. były wsie: Ostrowsko i Spicymierz (znacznie powyżej 400 mieszkańców, ponad 50 domów i areał przewyższający 1000 morgów), najmniejsze były zaś folwarki Ubysław i Zielenin oraz osada Wieszczyce (maksymalnie kilkadziesiąt osób i poniżej 10 domów). Folwarki, mimo słabego zaludnienia i stanu liczebnego zabudowy, miały jednak znaczną powierzchnię (np. Wielenin ponad 700 morgów). Zarówno w pierwszej połowie, jak i pod koniec XIX w., na jeden dom w większości wsi przydało średnio 6-8 osób. Wyjątkami były osady z dużymi folwarkami (np. Ubysław i Kościelnica, gdzie na jeden dom przypadało od 10 do nawet 20 osób w zależności od okresu). Przeważała zatem w nich zabudowa wielorodzinna typu: dwojaki, czworaki. W XIX w. największą dynamikę zmian zaludnienia wykazywały wsie: Kościelnica (o 41\%) i Wola Przedmiejska (o 76\%), wyłączając jednak małe osady, jak Wieszczyce i Ubysław, gdzie przyrost był 4-10 krotny. W pozostałych wsiach przyrost zaludnienia wynosił ok. 20-25\%. W Brzezinach, Człopach i Zieleninie liczba budynków mieszkalnych $\mathrm{z}$ lat 80 . XIX w. pozostała niezmienna lub była bardzo zbliżona do stanu z $1827 \mathrm{r}$. W pozostałych wsiach wzrost wahał się o 20-25\% (Wielenin, Kościelnica, Orzeszków, Wola Przedmiejska). Największy wzrost zanotowano w Spicymierzu (o 42\%), Ostrowsku (o 66\%), w małych osadach wzrost wynosił natomiast od 2,5 do 5 razy (Wieszczyce, Ubysław). Warto dodać, że w $1854 \mathrm{r}$. majorat obejmował folwarki: Kościelnica, Zielenin, Orzeszków, Wielenin i Ubysław, w których grunty orne, łąki, pastwiska i place zajmowały powierzchnię 1948 morgów (z lasem 4140 morgów) ${ }^{49}$. W II połowie XIX w. (po uwłaszczeniu chłopów) Kościelnica składała się z dwóch osad. Z dwóch osobnych jednostek osadniczych składał się również Orzeszków ${ }^{50}$.

W czasach funkcjonowania majoratu Tollów, oprócz kościoła w Uniejowie, budowle sakralne znajdowały się także w Spicymierzu i Wieleninie ${ }^{51}$. W $1865 \mathrm{r}$. został odnowiony drewniany kościół w Spicymierzu ${ }^{52}$. Według umowy donacyjnej hr. Toll był zobowiązany do corocznego bezpłatnego deputatu drewna sosnowego z oddanych mu lasów na rzecz probostw zlokalizowanych w Uniejowie i Wieleninie oraz dla szkół elementarnych w Ostrowsku, Uniejowie i Spicymierzu $^{53}$. Szkoła w Ostrowsku była początkowo jedyną szkołą z wykładowym językiem rosyjskim ${ }^{54}$. Według wykazu w 1883 r. szkoła początkowa znajdowała się także w Grzybkach ${ }^{55}$. Po reformach rolnych zgodnie $\mathrm{z}$ ukazami z lat 1864 i 1866 grunty pozostające w rękach Tollów przyłączono do folwarku Kościelnica. Z tego względu w latach 80. XIX w., majorat Uniejów-Kościelnica zmienił nazwę na majorat Kościelnica ${ }^{56}$.

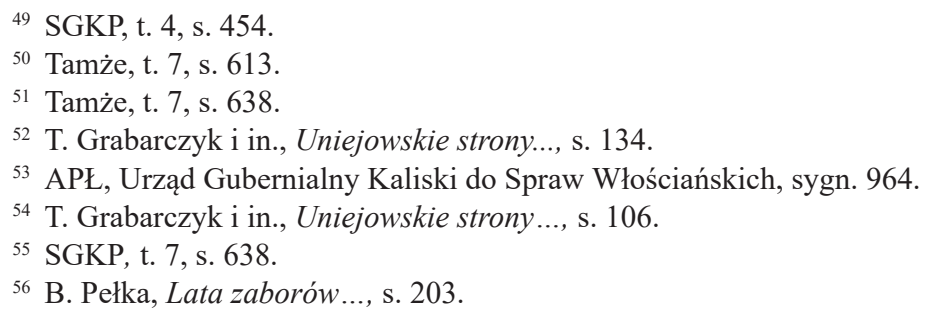


Tabela 1. Stan zaludnienia, zabudowy i powierzchni wsi majorackich pod Uniejowem w XIX w.

\begin{tabular}{|l|c|c|c|c|c|c|}
\hline \multirow{2}{*}{ Nazwa osady } & \multicolumn{2}{|c|}{$1827 \mathrm{r}}$. & \multicolumn{2}{c|}{1854 r. (bez folw.) } & \multicolumn{2}{c|}{ ok. 1880 r. } \\
\cline { 2 - 8 } & \multicolumn{2}{|c|}{ Liczba } & \multicolumn{2}{c|}{ Liczba } & \multicolumn{2}{c|}{ Liczba } \\
\cline { 2 - 8 } & osób & domów & morgów & domów & osób & domów \\
\hline Brzeziny & 94 & 14 & 445 & 18 & b.d. & 13 \\
\hline Człopy & 232 & 29 & 747 & 28 & b.d. & 30 \\
\hline Kościelnica (z folw.) & 285 & 28 & 347 & 27 & 402 & 34 \\
\hline Orzeszków (z folw.) & 267 & 31 & 516 & 35 & 321 & 40 \\
\hline Ostrowsko & 502 & 53 & 1522 & 87 & 623 & 88 \\
\hline Spicymierz & 434 & 50 & 1382 & 74 & 535 & 71 \\
\hline Ubysław (folw.) & 10 & 1 & b.d. & b.d. & 102 & 5 \\
\hline Wielenin (z folw.) & 344 & 44 & 787 & 29 & 412 & 53 \\
\hline Wieszczyce & 10 & 3 & 156 & 7 & 41 & 7 \\
\hline Wola Przedmiejska & 126 & 23 & 507 & 35 & 222 & 31 \\
\hline Zielenin (folw.) & 16 & 2 & b.d. & b.d. & 16 & 2 \\
\hline
\end{tabular}

Źródło: opracowanie własne na podstawie: Tabella miast, wsi i osad Królestwa Polskiego z wyrażeniem ich położenia i ludność alfabetycznie ułożona, t. 1 i 2, Warszawa 1827; Stownik Geograficzny Królestwa Polskiego i innych krajów słowiańskich, wyd. B. Chlebowski, F. Sulimierski, t. 1-14, Warszawa 1880-1914 (dane z II połowy XIX w. oparte w głównej mierze na: Pamjatnaja knižka Kališskoj gubernii na 1880 god, Kalisz 1880).

Po śmierci drugiego właściciela, majorat przejął jego syn Aleksander, urodzony i wychowany już w Uniejowie. Jego żona Anna Sommer był katoliczką. Posiadali pięcioro dzieci: Annę (ur. 1876), Aleksandra (ur. 1877), Eugeniusza (ur. 1880), Sergiusza (ur. 1893) oraz Zinaidę (ryc. 3). Tollowie po wybuchu I wojny światowej schronili się w majątku Anny Sommer-Toll w Stemplewie ${ }^{57}$. Folwark był podzielony na dwie części: po wschodniej stronie drogi znajdował się dwór, a po zachodniej zabudowa gospodarcza. W latach 80. XX w. dworek został rozebrany przez nowego właściciela. Jedyny zachowany budynek gorzelni poddano modernizacji w $1958 \mathrm{r}^{58} \mathrm{~W}$ roku 1918 do Aleksandra jr. Tolla należały majątki ziemskie: Kościelnica, Malczew, Orzeszków, Papiernia, Radzymin, Ubysław, Wania, Wielenin i Zielenin z gminy Kościelnica, Gąsiory z gminy Zelgoszcz, Grzybki z gminy Grzybki oraz Księże Młyny z gminy Niemysłów ${ }^{59}$. W 1919 r. majorat hr. Tolla przejęło Ministerstwo Rolnictwa i Dóbr Państwowych. W latach 1920-1935 rozparcelowane zostały grunty dawnych folwarków

\footnotetext{
${ }^{57}$ Tamże.

${ }^{58}$ G. Myszkorowska-Olczak, Zespoly folwarczne..., s. 108.

59 J. Kukulski, Generałowie carscy..., s. 377.
} 
rodziny Tollów ${ }^{60}$. Część z nich zachowała jedynie ślady swego istnienia w postaci zabudowań dworskich. Całkowitej likwidacji uległy zaś folwarki w Wieleninie i Zieleninie ${ }^{61}$. Zidentyfikować można ponadto liczne pozostałości po obecności rodziny Tollów w postaci obiektów dziedzictwa kulturowego. W tym kontekście warto wymienić w głównej mierze przebudowany przez hr. Aleksandra Tolla gotycki zamek arcybiskupów gnieźnieńskim wraz z utworzonym przez niego założeniem parkowym w stylu angielskim ${ }^{62}$. Kolejnym, charakterystycznym obiektem związanym z rodziną właścicieli majoratu jest cerkiew w stylu neobizantyjskim $^{63}$. Zbudowana w 1885 r. przez Aleksandra Tolla znajduje się obecnie w lesie na zachód od drogi Uniejów-Dąbie. Była ona miejscem pierwotnego pochówku hr. Aleksandra Tolla (zmarł w 1892 r. ${ }^{64}$ ), jego żony oraz syna Sergiusza. Zagadnienie dziedzictwa kulturowego związanego z działalnością rodziny Tollów oraz jego współczesny stan zachowania i zagospodarowania zostało jedynie zasygnalizowane i nie podlegało szczegółowej analizie, gdyż kwestia ta pozostaje poza sferą realizacji celu głównego artykułu.

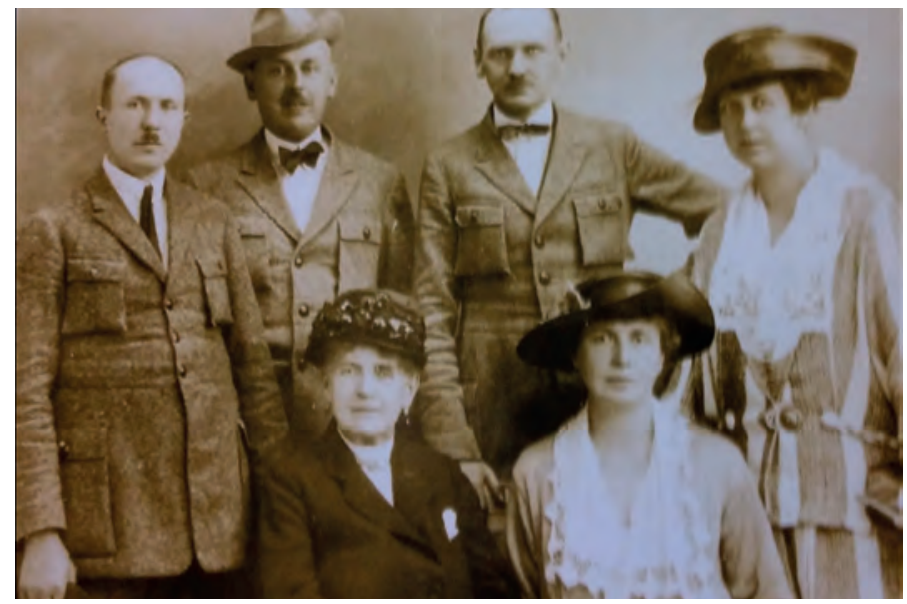

Ryc. 3. Rodzina Tollów na fotografii z lat 20. XX w.

Źródło: Archiwum Towarzystwa Przyjaciół Uniejowa, zbiory Tatiany Toll Yarigin

Jak uprzednio wspomniano w okresie istnienia majoratu miały miejsce reformy, które odzwierciedlały się w wyraźnych zmianach struktur społeczno-ekono-

${ }^{60}$ B. Pełka, Uniejów w okresie II Rzeczypospolitej, [w:] J. Szymczak (red.), Uniejów. Dzieje miasta, Uniejów-Lódź 1995, s. 238.

${ }^{61}$ G. Myszkorowska-Olczak, Zespoły folwarczne..., s. 110.

${ }^{62}$ Z. Ciekliński, J. Januszkiewicz, Uniejów, Łódź 1970, s. 8; J. Salm, Zabytki Uniejowa. Urbanistyka i architektura, [w:] Uniejów. Dzieje miasta, red. J. Szymczak, Uniejów-Łódź 1995, s. 437 i n.; Wojewódzki Konserwator Zabytków w Lodzi (dalej: WKZ), Karta inwentaryzacyjna zamku w Uniejowie, $\mathrm{nr}$ 256/714/A.

${ }^{63}$ WKZ, Karta inwentaryzacyjna cerkwi w Uniejowie, nr A-397/139; P. Zubowski, Cerkwie prawosławne Łodzi i regionu łódzkiego w dwudziestoleciu międzywojennym (1918-1939), Białystok 2014, s. 20.

${ }^{64}$ T. Wójcik, Tollowie.., s. 15. 
micznych oraz przestrzennych. Oczynszowanie chłopów wiązało się z wydzieleniem ziem włościańskich $\mathrm{w}$ formie scalonej i niekiedy przeniesieniem chłopów na nowe tereny ${ }^{65}$. W I połowie XIX w. rozpoczęły się procesy regulacji wsi, komasacji jak i parcelacji majątków ziemskich. Okres ten wiąże się nierzadko z zatarciem pierwotnych cech rozplanowania wsi ${ }^{6}$. Na przykładzie planu Spicymierza z 1804 r. (ryc. 4) widać, jak prezentował się układ przestrzenny wsi przed przejęciem dóbr uniejowskich przez rodzinę Tollów. Zagrody skupione były w południowo-wschodniej części wsi i tworzyły wyraźnie zwarty, lecz nieregularny układ wielodrogowy wzdłuż krawędzi równoległej do koryta rzecznego. Na zewnątrz siedliska zlokalizowane były rozłogi, tworzące nieregularne bloki, na ogół bez zachowania ciągłości przestrzennej z zagrodami ${ }^{67}$. W układzie Spicymierza dostrzec można elementy tzw. szachownicy pól, cechującej się nieregularnym układem gruntów, w którym przemieszane są ze sobą różnej wielkości działki należące do różnych właścicieli. Rozdrobnienie to zwiększyło się częściowo po uwłaszczeniu na skutek podziałów rodzinnych i parcelacji ${ }^{68}$. Zmiany rozplanowania dokumentuje plan Spicymierza w 1839 r. (ryc. 5). Osady włościańskie liczyły średnio 18 mórg, choć niektóre osiągały nawet 40 mórg ${ }^{69}$. Obserwujemy dalszy rozwój zabudowy wsi w kierunku zachodnim na tereny, które do tej pory nie były zagospodarowane. Dostrzegamy też rozbudowę w formie rzędowej w kierunku północnym, wzdłuż drogi prowadzącej od kościoła do Uniejowa, równolegle do rzeki Warty ${ }^{70}$.

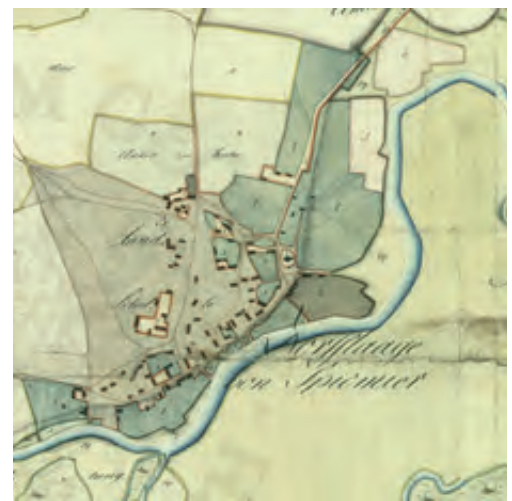

Ryc. 4. Plan wsi Spicymierz z 1804 r. (przed utworzeniem majoratu)

Źródło: AGAD w Warszawie, zbiór kart., sygn. 344-4

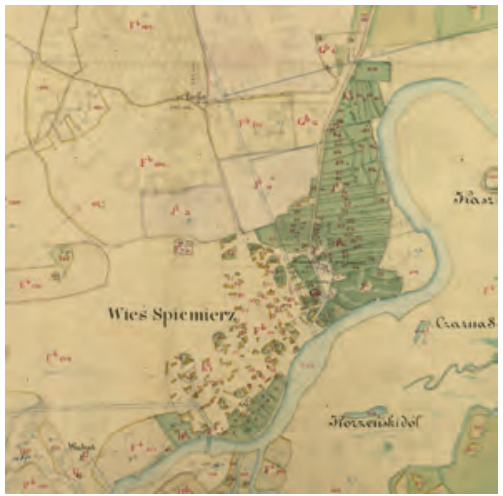

Ryc. 5. Plan wsi Spicymierz z 1839 r. (po utworzeniu majoratu i regulacji) Źródło: AGAD w Warszawie, zbiór kart., sygn. $185-1$

${ }^{65}$ H. Szulc, Morfogeneza osiedli wiejskich w Polsce, Wrocław 1995, s. 75.

${ }^{66}$ T. Figlus, Zróżnicowanie morfogenetyczne wsi na obszarze gminy Uniejów, „Biuletyn Uniejowski” 2014, t. 3, s. 99.

${ }^{67}$ Tenże, Rozwój uktadu ruralistycznego Spicymierza na tle dziejów osadnictwa w świetle badań geograficzno-historycznych i archeologicznych, „Biuletyn Uniejowski” 2015, t. 4, s. 88; J. Kukulski, Donacje paskiewiczowskie..., s. 67.

${ }^{68}$ H. Brodowska, Historia społeczno-gospodarcza..., s. 416.

${ }^{69}$ SGKP, t. 11, s. 109.

${ }^{70}$ T. Figlus, Rozwój uktadu ruralistycznego ..., s. 89. 
$\mathrm{Na}$ obszarze dóbr uniejowskich istniały liczne folwarki. Towarzyszyły im niekiedy zespoły dworskie. Zlokalizowane one były w obrębie siedliska, na zwieńczeniu osi kompozycyjnych. Do czasu wspomnianej uprzednio separacji gruntów, pierwotnie towarzyszyły im rozłogi niwowo-łanowe z przemieszaniem własności kmiecej i folwarcznej ${ }^{71}$. Na badanym obszarze powstał ponadto nowy folwark Aleksandria, stanowiący autonomiczny nowy punkt osadniczy ${ }^{72}$. Utworzona jednostka osadnicza obejmowała zabudowę gospodarczą, sprzężoną z niewielką kolonią zamieszkaną przez zagrodników ${ }^{73}$.

W wyniku komasacji i regulacji, a także procesów parcelacyjnych powstał nowy typ wsi w postaci tzw. rzędówki ${ }^{74}$. Rzędówki różnej długości, ciągnące się nawet kilka kilometrów występują $\mathrm{w}$ dwóch formach: $\mathrm{z}$ zabudową jednostronną (np. Kościelnica) i dwustronną (np. Ostrowsko). Zalecano reorganizację osad kolonijnych tak, aby w miarę możliwości chłopi nie ponieśli strat zarówno w ilości, jak i jakości użytków rolnych. Nie pozwalano na zmniejszanie obszaru gruntu i zamianę ziem lepszych na gorsze. Dopuszczano natomiast możliwość zwiększenia areału chłopskiego ${ }^{75}$.

W obrębie dóbr uniejowskich powstawały także liczne kolonie i osiedla przemysłowe ${ }^{76}$. W Orzeszkowie po przejęciu folwarku, rodzina Tollów wybudowała pałac, budynki towarzyszące i rowy melioracyjne. Równocześnie rozwinęło się rzemiosło, świadczące usługi na potrzeby folwarku. Rzemieślnicy i służba stworzyli koło pałacu osadę zwaną potocznie małym Orzeszkowem. Rzemieślnicy - należący do cechów w Uniejowie - mieli świadczyć usługi mieszkańcom całej wsi. Tollowie zachowali w Orzeszkowie i jego okolicach 5676 morgów zie$\mathrm{mi}^{{ }^{77}}$. W II połowie XIX w. wieś składała się z dwóch części i posiadała 34 domy, 193 mieszkańców oraz 516 mórg, natomiast folwark Orzeszków zamieszkiwało 128 mieszkańców. W obrębie osady folwarcznej znajdowało się 6 domów ${ }^{78}$.

Przeszkodą w urządzaniu dóbr donacyjnych były posiadłości proboszczy. Przedstawiciele duchowieństwa starali się o wyznaczenie lepszych gruntów dla swoich posiadłości i zabiegali o powiększenie należących do nich przestrzeni ${ }^{79}$. W 1849 r. kościół w Kościelnicy powiększył swoje majętności z 50 mórg i 171 prętów do wielkości 54 morgów i 141 prętów. W Spicymierzu ziemie proboszcza zostały powiększone tylko o parę prętów: z 68 morgów i 54 prętów na 68 morgów i 284 pręty. W Wieleninie grunty probostwa zostały powiększone z 145 mórg i 3 prętów do 146 morgów $^{80}$.

\footnotetext{
${ }^{71}$ Tenże, Zróżnicowanie morfogenetyczne..., s. 101.

${ }^{72}$ APŁ, Urząd Gubernialny Kaliski do Spraw Włościańskich, sygn. 964.

${ }^{73}$ T. Figlus, Zróżnicowanie morfogenetyczne..., s. 101.

${ }^{74}$ H. Szulc, Morfogeneza osiedli..., s. 75.

75 J. Kukulski, Państwo - chłopi-kościół ..., s. 95.

${ }^{76}$ H. Szulc, Morfogeneza osiedli..., s. 77.

77 T. Grabarczyk i in., Uniejowskie strony..., s. 101.

${ }^{78}$ SGKP, t. 7, s. 613.

${ }^{79}$ J. Kukulski, Donacje paskiewiczowskie..., s. 77 i n.

${ }^{80}$ APŁ, Urząd Gubernialny Kaliski do Spraw Włościańskich, sygn. 964.
} 
Dalsze procesy przekształceń sieci osadniczej w dobrach rodziny Tollów powiązane były z uwłaszczeniem chłopów. Doszło w tym okresie do kolejnych zmian rozplanowania wsi ${ }^{81}$. Prowadzone odgórnie procesy komasacyjno-separacyjne rozłogów, regulacje siedlisk oraz parcelacje majątków folwarcznych miały na celu częściową lub całkowitą transformację układów ruralistycznych. Wsie poregulacyjne przyjmowały najczęściej charakter rzędówek, zwykle z jedną osią siedliskową i jednostronną zabudową. W wielu przypadkach nowe struktury morfologiczne w postaci tzw. wsi sznurowych z indywidualnym, pasmowym układem rozłogów zastępowały dawne, zwarte układy ulicówek i owalnic o metryce średniowiecznej z niwowym układem gruntowym. Przykładem takiej formy transformacji może być wieś Ostrowsko (ryc. 6 i 7). Przykładami nowych układów kolonijnych powstałych w wyniku parcelacji gruntów folwarcznych mogą być natomiast wsie: Spicymierz Kolonia, Orzeszków Kolonia i Wielenin Kolonia ${ }^{82}$.

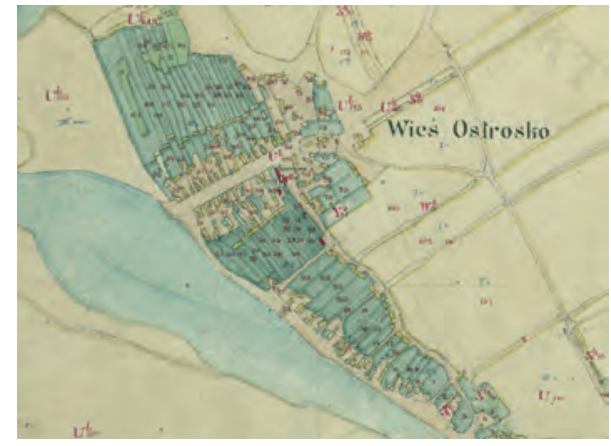

Ryc. 6. Plan wsi Ostrowsko z 1839 r.

Źródło: AGAD w Warszawie, Zbiór kart., sygn. 185-1.

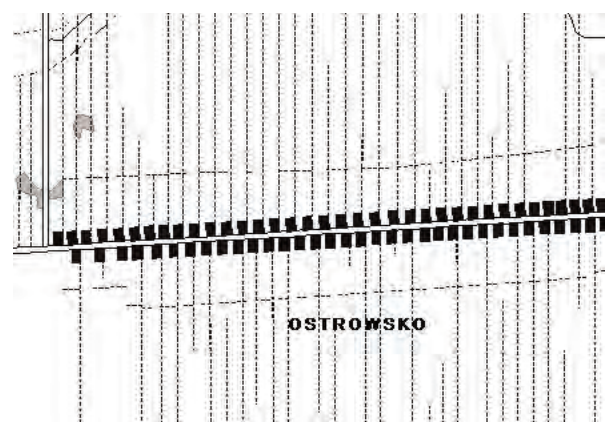

Ryc. 7. Odrys planu wsi Ostrowsko z $1861 \mathrm{r}$. Źródło: AGAD w Warszawie, Zbiór kart., sygn. 184-4

Po uwłaszczeniu, chłopi zaczęli dążyć do zwiększenia stanu posiadania gruntów i do lepszego ich wykorzystania. Ze wzrostem ogólnego obszaru własności chłopskiej zwiększyła się powierzchnia pól ornych, ogrodów, łąk i pastwisk. Lasy i nieużytki zmieniano stopniowo na uprawne grunty ${ }^{83}$. W $1867 \mathrm{r}$. w celu likwidacji niewygodnej szachownicy gruntów dokonano zamiany: 23 gospodarzy dokonało wymiany 55 mórg i 153 prętów ziemi w Uniejowie na ziemie folwarku Kościelnica oraz Uniejowa Poduchownego o powierzchni 22 mórg i 54 prętów ${ }^{84}$.

\footnotetext{
81 J. Kukulski, Donacje paskiewiczowskie..., s. 86 i n.

${ }^{82}$ T. Figlus, Zróżnicowanie morfogenetyczne..., s. 104.

${ }^{83}$ H. Brodowska, Historia społeczno-gospodarcza..., s. 299.

${ }^{84}$ B. Pełka, Lata zaborów..., s. 197.
} 


\section{PODSUMOWANIE}

W artykule podjęto próbę ukazania specyfiki rozwoju dóbr majorackich powstałych w wyniku tzw. donacji paskiewiczowskich po klęsce powstania listopadowego. Na przykładzie klucza majątkowego w rejonie Uniejowa udało się wychwycić szczegóły dotyczące genezy tworzenia majoratu, zasad jego funkcjonowania i rozwoju w XIX w., biorąc pod uwagę aspekty prawno-organizacyjne i gospodarcze. Badany majorat znajdował się przeszło 80 lat w rękach rodziny Tollów. Ich rządy przypadły na okres wielkich reform agrarnych. Oprócz zmian na płaszczyźnie społeczno-ekonomicznej, reformy miały także wpływ na transformację przestrzenną struktur osadniczych, której skutki widoczne są do tej dziś w krajobrazie kulturowym. W opracowaniu poza aspektem zmian zaludnienia, stanu liczebnego zabudowy i powierzchni gruntów zwrócono szczególną uwagę na rolę własności majorackiej w procesie przyśpieszonych $\mathrm{w}$ stosunku do dóbr prywatnych, przeduwłaszczeniowych zmian układów ruralistycznych. W związku z komasacją i separacją gruntów włościańskich od folwarcznych oraz reorganizacją siedlisk, wsie podlegały intensywnej regulacji, a część z nich przyjęła formę regularnych rzędówek z indywidualnym, pasmowym układem rozłogów. Na proces ten nałożyły się zmiany będące pokłosiem reformy uwłaszczeniowej. Po tym jak chłopi uzyskali ziemię na własność, doszło do dalszej reorganizacji wsi, zamiany gruntów oraz sukcesywnej parcelacji skutkującej rozwojem układów typu kolonijnego.

\section{Bibliografia}

\section{Źródla rękopiśmienne}

Archiwum Główne Akt Dawnych w Warszawie, Zbiór kartograficzny, Dobra Rządowe Ekonomii Uniejów na Mapie Ogólnej Dóbr i Lasów Rządowych w Królestwie Polskim, ułożonej przez J. Rakowskiego w 1825 r., sygn. 88-10.

Archiwum Główne Akt Dawnych w Warszawie, Zbiór kartograficzny, Plan wsi Spicymierz z 1804 r., sygn. 344-4.

Archiwum Główne Akt Dawnych w Warszawie, Zbiór kartograficzny, Plan wsi Spicymierz z 1839 r, sygn. 185-1.

Archiwum Główne Akt Dawnych w Warszawie, Zbiór kartograficzny, Plan wsi Ostrowsko z 1839 r, sygn. 185-1.

Archiwum Główne Akt Dawnych w Warszawie, Zbiór kartograficzny, Plan wsi Ostrowsko z $1861 \mathrm{r}$, sygn. 184-4.

Archiwum Państwowe w Łodzi, Rząd Guberni Kaliskiej, sygn. 2334.

Archiwum Państwowe w Łodzi, Urząd Gubernialny Kaliski do Spraw Włościańskich, sygn. 964. 


\section{Źródla drukowane}

Archiwum Towarzystwa Przyjaciół Uniejowa, zbiory Tatiany Toll Yarigin.

Dziennik Praw Królestwa Polskiego, 1836, t. 17; 1837, t. 20; 1866, t. 66.

Pamjatnaja knižka Kališskoj gubernii na 1880 god, Kalisz 1880.

Tabella miast, wsi i osad Królestwa Polskiego z wyrażeniem ich położenia i ludność alfabetycznie ułożona, t. 1 i 2, Warszawa 1827.

Wojewódzki Konserwator Zabytków w Łodzi, Karta inwentaryzacyjna cerkwi w Uniejowie, nr A-397/139.

Wojewódzki Konserwator Zabytków w Łodzi, Karta inwentaryzacyjna zamku w Uniejowie, nr 256/714/A.

\section{Piśmiennictwo}

Bernhardi von T., Denkwürdigkeiten aus dem Leben des Grafen von Toll, 2. Auflage, Leipzig 1866.

Brodowska H., Historia społeczno-gospodarcza chłopów w zaborze rosyjskim, [w:] Historia chłopów polskich, red. S. Inglot, t. 2, Wrocław 1972.

Chilczuk M., Osadnictwo wiejskie Polski (Formy i uktady przestrzenne), Warszawa 1970.

Chomać R., Zmiany własności struktury agrarnej guberni kaliskiej w latach 1864-1914, „,Rocznik Kaliski”, 1968, 1.

Ciekliński Z., Januszkiewicz J., Uniejów, Łódź 1970.

Figlus T., Rozwój osadnictwa wiejskiego w kluczu uniejowskim dóbr arcybiskupów gnieźnieńskich, „Biuletyn Uniejowski” 2016, t. 5.

Figlus T., Zróżnicowanie morfogenetyczne wsi na obszarze gminy Uniejów, „Biuletyn Uniejowski” 2014, t. 3 .

Figlus T., Rozwój układu ruralistycznego Spicymierza na tle dziejów osadnictwa w świetle badań geograficzno-historycznych i archeologicznych, „Biuletyn Uniejowski” 2015, t. 4.

Genealogisches Handbuch der baltischen Ritterschaften, Teil 2: Estland, Görlitz 1930.

Grabarczyk T., Kowalska-Pietrzak A., Szymczak J., Uniejowskie strony - karty z przeszłości odległej, nieznanej i bliskiej gminy Uniejów, Łódź-Uniejów 2008.

Grabski W., Bezrolni i majoraty, „Biblioteka Warszawska” 1910, 70 (829).

Grabski W., Historia wsi w Polsce, Warszawa 2004.

Groniowski K., Uwłaszczenie chtopów w Polsce, Warszawa 1976.

Krantz L., Zamek w Uniejowie, Warszawa-Poznań 1980.

Kukulski J., Donacje paskiewiczowskie w okresie reform agrarnych, Kielce 1987.

Kukulski J., Generałowie carscy i ich majątki ziemskie w Królestwie Polskim (1835-1920), Warszawa 2007.

Kukulski J., Państwo - chłopi - kościół w okresie wielkich reform ziemskich Królestwa Polskiego w latach 1768-1890, Piotrków Trybunalski 2007.

Leszczyński M., Ostrołęka 1831, Warszawa 2011.

Myszkorowska-Olczak G., Zespoły folwarczne na terenie gminy Uniejów, „Biuletyn Uniejowski” 2013 , t. 2.

Pełka B., Lata zaborów, [w:] Uniejów. Dzieje miasta, red. J. Szymczak, Uniejów-Lódź 1995.

Pełka B., Uniejów w okresie II Rzeczypospolitej, Uniejów. Dzieje miasta, red. J. Szymczak, Uniejów-Lódź 1995. 
Piątkowski S., Majorat Iwana Paskiewicza w guberni lubelskiej (1840-1856). Karta z biografii Księcia Namiestnika Królestwa Polskiego, [w:] Studia z dziejów ziemian 1795-1944, red. A. Koprukowniak, Lublin 2005.

Salm J., Zabytki Uniejowa. Urbanistyka i architektura, [w:] Uniejów. Dzieje miasta, red. J. Szymczak, Uniejów-Lódź 1995.

Stankiewicz Z., Zasady uwłaszczenia chtopów w Królestwie Polskim, [w:] Studia i Materiały do Dziejów Łodzi i okręgu łódzkiego. Uwłaszczenie chłopów i mieszczan rolników, red. H. Brodowska, Łódź 1966.

Stownik Geograficzny Królestwa Polskiego i innych krajów słowiańskich, red. F. Sulimierski, B. Chlebowski, t. 1-14, Warszawa 1880-1914.

Szczepański B., Rozwój rolnictwa, [w:] Dzieje Wielkopolski, t. 2, red. W. Jakóbczyk, Poznań 1973.

Szulc H., Morfogeneza osiedli wiejskich w Polsce, Wrocław 1995.

Tuderek A., Wieś Księżomierz - stosunki gospodarczo-spoteczne w XIX stuleciu, „Teka Komisji Historycznej OL Lublin" 2009, 6.

Wójcik T., Tollowie, „W Uniejowie - Pismo Towarzystwa Przyjaciół Uniejowa” 2016, nr 67.

Zubowski P., Cerkwie prawosławne Łodzi i regionu łódzkiego w dwudziestoleciu międzywojennym (1918-1939), Białystok 2014.

[Artykuł wpłynął: maj 2017; zaakceptowany: czerwiec 2017]

\section{ORIGIN OF ENTAIL AND SETTLEMENT RELATIONS IN THE ESTATE OF THE TOLL FAMILY NEAR UNIEJÓW}

\section{Summary}

The article presents settlement relations in an entailed estate near Uniejów in the 19th and the beginning of the 20th century. Geo-historical analysis covers the issue of settlement origins and transformations, including the morphology of the countryside. It attempts a reconstruction of the circumstances of the origin of donation on the basis of a ukase (an edict of the tsar) of 1836, and presents, from the spatial perspective, the development of selected social and economic aspects of the functioning of the entailed estate in question. Special attention is devoted to changes in rural settlement resulting from two massive agrarian reforms which caused the transformation of rural settlement systems.

Keywords: historical geography, settlement, village, Toll family, entail, 19th century, Uniejów 